\title{
A New Spectrophotometric Method for Determination of Penicillamine in Pharmaceutical Formulation Using 1, 2-naphthoquine-4-sulfonate (NQS)
}

\author{
Abdalla Ahmed Elbashir* and Salwa Fwad Awad \\ University of Khartoum, Faculty of Science, Chemistry Department, Khartoum, P.O. Box 321, Sudan
}

\begin{abstract}
A rapid, simple and sensitive method for the determination of D-Penicillamine using sodium 1,2-naphthoquine4-sulfonate (NQS) has been developed. The method is based on the fact that a brown product can be formed by the reaction between D-Penicillamine and sodium NQS in a buffer solution of a pH 12.0. Beer's law is obeyed in the range $10-30 \mu \mathrm{g} / \mathrm{mL}$ of D-Penicillamine at maximum wavelength of $425 \mathrm{~nm}$. The linear regression equation of the calibration curve is $A=0.1684+0.01624 \mathrm{C}(\mu \mathrm{g} / \mathrm{mL})$, with a linear regression correlation coefficient of 0.997 . The detection limit is $3.12 \mu \mathrm{g} / \mathrm{mL}$ and the recovery rate is in the range of $99.21-108.2 \%$. The method has been successfully applied to the determination of D-Penicillamine in pharmaceutical formulation.
\end{abstract}

Keywords: Spectrophotometric; D-Penicillamine; Pharmaceutical formulation; Sodium1,2-naphthoquinone-4-sulfonic (NQS)

\section{Introduction}

The D-Penicillamine, 3-mercapto-D-valine, is the characteristic acid degradation product of $\beta$ - lactam antibiotics. It is a chelating agent, which is used to aid the elimination of copper in the treatment of hepatolenticular degeneration (Wilson's disease) [1]. It has been also used in cystinuria, in heavy metal poisoning and for the treatment of rheumatoid arthritis [2].

Several methods have been reported for the analysis of D-Penicillamine in both pharmaceutical preparations and biological samples. These methods include colorimetry [3-10], fluorimetry [11], chromatography [12-19], flow injection analysis [20-22], electrophoresis [23-25], potentiometry [26], voltammetry [27-29] and NMR spectrometry [30]. Due to the lack of chromophore and or auxochrome in D-penicillamine molecule, direct spectrophotometry cannot be used for its analysis.

Most of the reported colorimetric methods are time consuming or lacking selectivity due to the problem of interference with degradation product of coloring agents [7,9]. Therefore the need for a fast, sensitive, simple and selective method is obvious, especially for routine quality control analysis of pharmaceutical products containing D-penicillamine.

NQS has been used as a color-developing reagent in the spectrophotometric determination of many pharmaceutical amines [31-39]. The applications of NQS for determination of pharmaceutical bearing amine group have recently been reviewed by Elbashir et al. [39]. The reaction between NQS and D-penicillamine has not investigated yet. Therefore, the present study was devoted to investigate the reaction between NQS and D-penicillamine, and use this color reaction in the development of simple rapid spectrophotometric method for determination of $\mathrm{D}$-penicillamine in its dosage form.

\section{Experimental}

\section{Apparatus}

The spectral measurements were carried out by using a spectrophotometer model Shimadzu 1800, with quartz cells of $1 \mathrm{~cm}$ optical path length. $\mathrm{pH}$ meter was used for $\mathrm{pH}$ measurements.

\section{Material and reagents}

D-penicillamine, sodium-1,2-naphthoquinone-4-sulfonate (NQS) solution of $0.2 \%(\mathrm{w} / \mathrm{v})$ was prepared by dissolving $0.2 \mathrm{~g}$ in distilled water, transferred into a $100 \mathrm{~mL}$ volumetric flask and diluted to the mark with distilled water and mixed well. The solution was freshly prepared and protected from light during use. Buffer solution of $\mathrm{pH}$ 12.0 was prepared by mixing $100 \mathrm{~mL}$ of $0.2 \mathrm{M}$ aqueous solution of sodium dihydrogen phosphate with $50 \mathrm{~mL}$ of $0.2 \mathrm{M}$ aqueous solution of sodium hydroxide in $100 \mathrm{~mL}$ volumetric flask, and adjusted by $\mathrm{pH}$ meter.

\section{Preparation of standard and sample solutions}

Stock standard solution of D-penicillamine $(1000 \mu \mathrm{g} / \mathrm{mL})$ : An accurately $0.1 \mathrm{~g}$ of $\mathrm{D}$-penicillamine standard was dissolved in distilled water, transferred into a $100 \mathrm{~mL}$ volumetric flask and diluted to the mark with water and mixed well. This stock solution was further diluted with water to obtain working solutions in the ranges of $5-30 \mu \mathrm{g} / \mathrm{mL}$.

Sample solution: Five capsules (D-penicillamine $250 \mathrm{mg} /$ capsule) were weighed, and finely powdered. A portion of the power equivalent to $10 \mathrm{mg}$ of the drug was weighed and dissolved in distilled water then transferred into $100 \mathrm{~mL}$ volumetric flask to give a solution of 100 $\mu \mathrm{g} / \mathrm{mL}$. The solution was completed to the mark with distilled water, shaken well, filtered and then analyzed by the following procedure.

\section{Procedure}

A $1.0 \mathrm{~mL}$ of $200 \mu \mathrm{g} / \mathrm{mL}$ of D-penicillamine was transferred into $10 \mathrm{ml}$ volumetric flask, $1.0 \mathrm{~mL}$ of $0.2 \%$ sodium-1,2-naphthoquinone -4-sulfonate was added and followed by $1.0 \mathrm{~mL} \mathrm{pH} 12.0 \mathrm{NaH}_{2} \mathrm{PO}_{4}^{-}$

\footnotetext{
*Corresponding author: Abdalla Ahmed Elbashir, University of Khartoum, Faculty of Science, Chemistry Department, Khartoum, P.O. Box 321, Sudan, E-mail: hajaae@yahoo.com

Received January 07, 2013; Accepted January 23, 2013; Published January 26, 2013

Citation: Elbashir AA, Awad SF (2013) A New Spectrophotometric Method for Determination of Penicillamine in Pharmaceutical Formulation Using 1, 2-naphthoquine-4-sulfonate (NQS). J Pharmacovigilance 1: 105. doi:10.4172 2329-6887.1000105

Copyright: (c) 2013 Elbashir AA, et al. This is an open-access article distributed under the terms of the Creative Commons Attribution License, which permits unrestricted use, distribution, and reproduction in any medium, provided the original author and source are credited.
} 
$\mathrm{NaOH}$ buffer solution. The reaction was completed to volume with distilled water, and the resulting solution was measured at $452 \mathrm{~nm}$ against reagent blank treated similarly.

\section{Job's method}

The Job's method of continuous variation [40] was employed. Master equimolar $\left(1 \times 10^{-3} \mathrm{M}\right)$ aqueous solution of D-penicillamine and NQS were prepared. Series of $10 \mathrm{~mL}$ portions of the master solution of D-penicillamine and NQS were made up comprising different complementary proportions $(1: 9, \ldots 9: 1$, inclusive) in $10 \mathrm{~mL}$ volumetric flask containing $1 \mathrm{ml}$ of buffer solution $(\mathrm{pH}=12.0)$. The solution was further manipulated as described under the general recommended procedures.

\section{Results and Discussion}

\section{Absorption spectra}

The absorption spectrum of D-penicillamine was recorded against water (Figure 1), it was found that $\mathrm{D}$-penicillamine exhibits a maximum absorption peak $\left(\lambda_{\max }\right)$ at $198 \mathrm{~nm}$. Because of highly blue shifted $\lambda_{\text {max }}$ of $\mathrm{D}$-penicillamine, its determination in the dosage form based on the direct measurement of its absorption for ultraviolet is susceptible to potential interferences from the common excipients. Therefore, derivatization of D-penicillamine red-shifted light-absorbing derivative was necessary. The reaction between $\mathrm{D}$-penicillamine and NQS was performed, and the absorption spectrum of the product was recorded against reagent blank (Figure 1). It was found that the product is brown colored exhibiting $\lambda_{\text {max }}$ at $452 \mathrm{~nm}$, and the $\lambda_{\text {max }}$ of NQS was $362 \mathrm{~nm}$. The $\lambda_{\max }$ of D-penicillamine- NQS derivative was red-shifted, eliminating any potential interference. Therefore, the measurements were carried out at $452 \mathrm{~nm}$.

\section{Optimization of variables}

Effect of $\mathbf{p H}$ : The effect of $\mathrm{pH}$ on the reaction between D-penicillamine and NQS was examined by varying $\mathrm{pH}$ form 6.0 to 13.5. As shown in figure 2, the absorbance of the product is low at $\mathrm{pH}$ 6.0 , indicate that D-penicillamine has difficulty to react with (NQS) in acidic media. This was possibly due to the existence of the amino group of D-penicillamine in the form of hydrochloride salt, thus it loses its nucleophilic substitution capability.

As the $\mathrm{pH}$ increased, the readings increased rapidly, as the amino

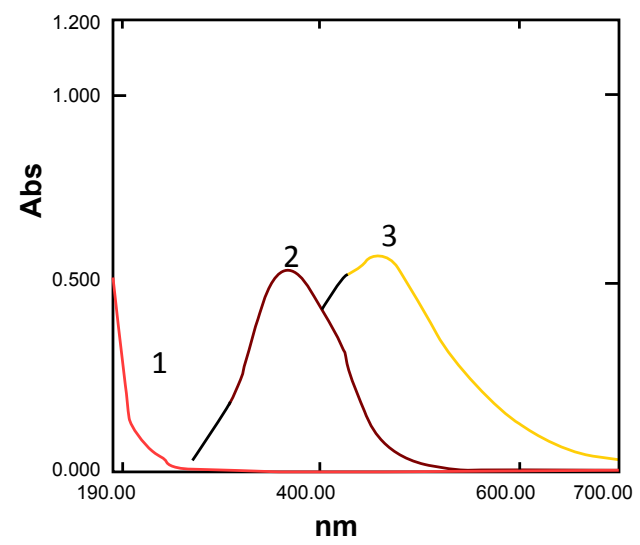

Figure 1: Absorption spectra of D-penicillamine $(20 \mu \mathrm{g} / \mathrm{mL})$ against water line (1), NQS $(0.2 \%, w / v)$ against water line (2), and the reaction product of D-penicillamine $(20 \mu \mathrm{g} / \mathrm{mL})$ with NQS against reagent blank line (3).

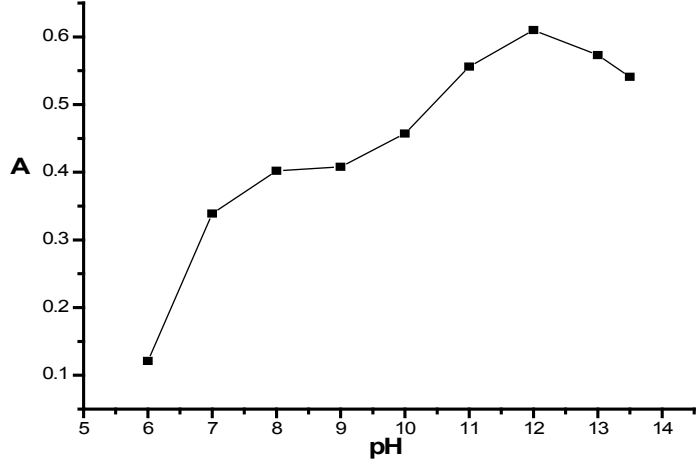

Figure 2: Effect of $\mathrm{pH}$ on absorbance of product concentration of D-penicillamine $20 \mu \mathrm{g} / \mathrm{mL}$.

group of D-penicillamine turns into the free amino group, thus facilitating the nucleophilic substitution. The maximum readings were attained at $\mathrm{pH}$ values of 12.0 . At $\mathrm{pH}$ values more than 12.0 decrease in the readings occurred. This was attributed probably to the increase in the amount of hydroxide ion that holds back the reaction of D-penicillamine with NQS.

Effect of temperature and standing time: The absorbance of product I was determined at different time (Figure 3). Keeping other conditions unchanged, the absorbance of the product I was measured after standing for different time periods at $25^{\circ} \mathrm{C}$. The results show that D-penicillamine react with $\mathrm{NQS}$ at $25^{\circ} \mathrm{C}$ and the absorbance begins to increase instantly and becomes constant after $20 \mathrm{~min}$. Furthermore, it is also observed that the absorbance remain constant for $30 \mathrm{~min}$.

Effect of NQS concentration: The studying of NQS concentrations revealed that the reaction was dependent on NQS reagent. The highest absorption intensity was attained at NQS concentration of $0.4 \%(\mathrm{w} / \mathrm{v})$, and higher concentration of NQS $(0.5 \%, w / v)$ had no effect on the absorption values, as shown in figure 4 .

Effect of amount of the buffer: Keeping $\mathrm{pH}$ at 12.0, the effect of amount of buffer solution on the absorbance of product I was also studied. It shows that the absorbance of product I enhances rapidly with the rise of amount of buffer solution, and becomes maximal when the amount of buffer solution is $1.0 \mathrm{~mL}$. Therefore, the amount of 1.0 $\mathrm{mL}$ buffer solution was selected to ensure the highest absorbance of product $\mathrm{I}$, as shown in figure 5 .

\section{Validation of the method}

Calibration curve: Calibration curve for the determination of D-penicillamine by it reaction with NQS was constructed by plotting the absorbance's as a function of the corresponding concentrations. The regression equation for the results was $\mathrm{A}=0.1684+0.01624 \mathrm{C}$ ( $\mathrm{r}=0.997)$, where A is the absorbance at $452 \mathrm{~nm}, \mathrm{C}$ is the concentration of D-penicillamine in $\mu \mathrm{g} / \mathrm{mL}$ in the range of $10-30 \mu \mathrm{g} / \mathrm{mL}$, and $\mathrm{r}$ is correlation coefficient. The limit of detection (LOD) and limit of quantification (LOQ) were determined according to the following formula $\mathrm{LOD}=3.3 \times \mathrm{SDa} / \mathrm{b}$, and $\mathrm{LOQ}=10 \times \mathrm{SDa} / \mathrm{b}, \mathrm{SDa}$ is the standard deviation of intercept, $\mathrm{b}$ is the slope. The LOD and LOQ were found to be 3.12 and $9.44 \mu \mathrm{g} / \mathrm{mL}$, respectively, (Table 1 ).

Robustness: Robustness was examined by evaluating the influence of small variation in the method variables on its analytical performance. In these experiments, one parameter was changed whereas the others 
Citation: Elbashir AA, Awad SF (2013) A New Spectrophotometric Method for Determination of Penicillamine in Pharmaceutical Formulation Using 1 , 2-naphthoquine-4-sulfonate (NQS). J Pharmacovigilance 1: 105. doi:10.4172/2329-6887.1000105

Page 3 of 5

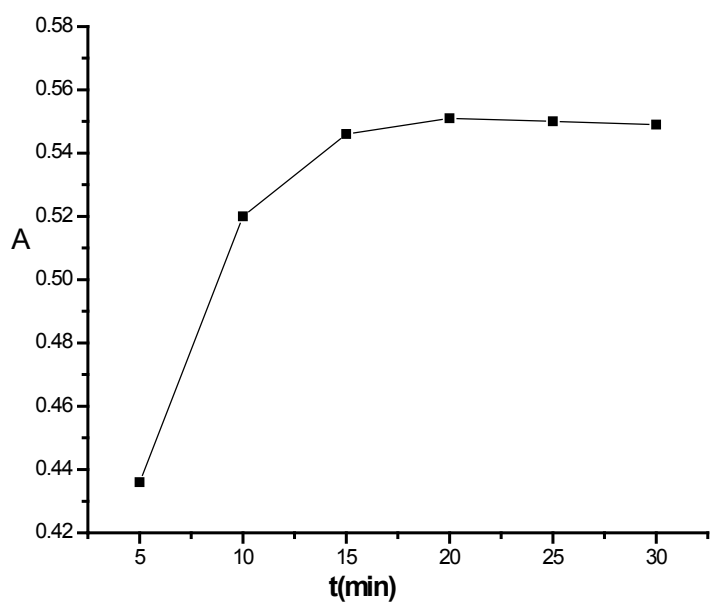

Figure 3: The effect of standing time on determination of D-penicillamine.

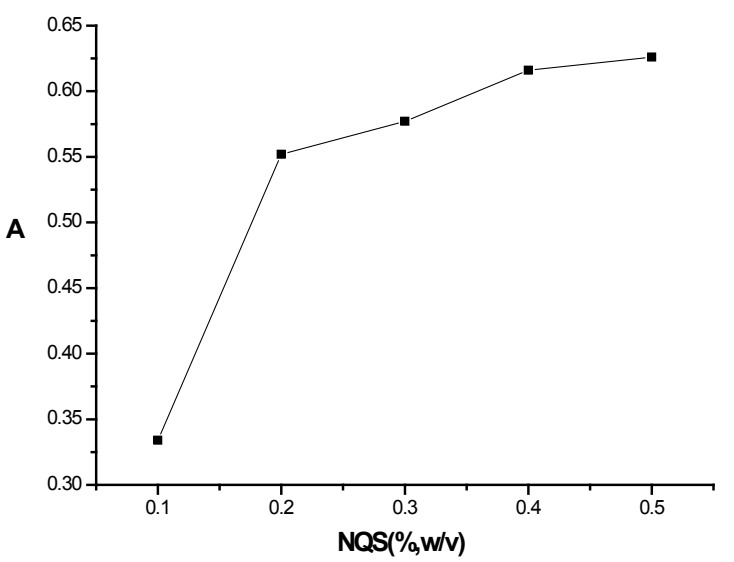

Figure 4: The effect of NQS concentration on determination of D-penicillamine.

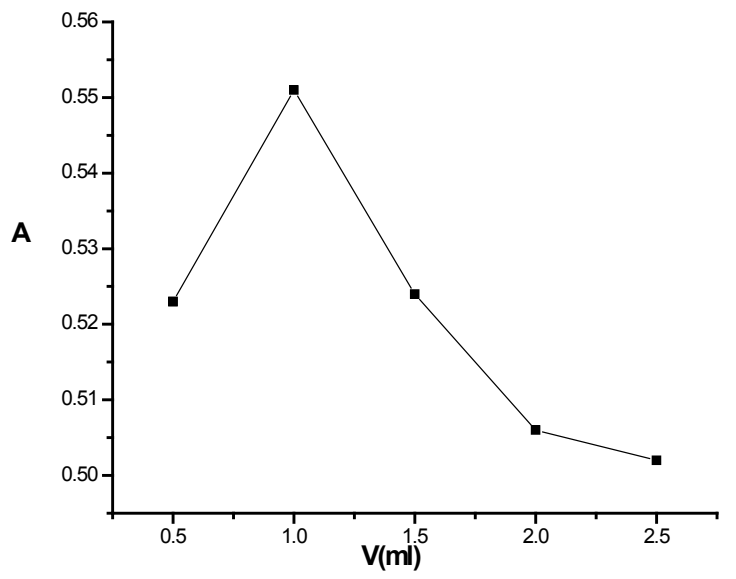

Figure 5: The effect of amount of the buffer on determination of D-penicillamine.

were kept unchanged, and the recovery percentage was calculated each time. It was found that small variation in the method variables did not significantly affect the procedures; recovery values were recorded in table 2 . This indicated the reliability of the proposed method to routine application for the analysis of D-penicillamine.

\begin{tabular}{|c|c|}
\hline Parameter & Value \\
\hline Measurement wavelength $(\mathrm{nm})$ & 452 \\
\hline Linear range $(\mu \mathrm{g} / \mathrm{mL})$ & $10-30$ \\
\hline Intercept & 0.1682 \\
\hline Standard deviation of the intercept & 0.0153 \\
\hline Slope & 0.0162 \\
\hline Standard deviation of the slope & 0.0007 \\
\hline Correlation coefficient $(\mathrm{r})$ & 0.9970 \\
\hline Limit of detection, LOD $(\mu \mathrm{g} / \mathrm{mL})$ & 3.12 \\
\hline Limit of quantification, $\mathrm{LOQ}(\mu \mathrm{g} / \mathrm{mL})$ & 9.44 \\
\hline
\end{tabular}

Table 1: Parameters for the performance of the proposed method.

\begin{tabular}{|c|c|}
\hline Parameters & Recovery $(\% \pm \mathbf{S D})^{\mathbf{a}}$ \\
\hline Recommended conditions & $104.6 \pm 0.01$ \\
\hline NQS concentration $(\%, \mathrm{w} / \mathrm{v})$ & \\
\hline 0.15 & $93.3 \pm 0.013$ \\
\hline 0.25 & $96.7 \pm 0.01$ \\
\hline Buffer solution $(\mathrm{pH})$ & \\
\hline 11.8 & $93.8 \pm 0.005$ \\
\hline 12.2 & $104.8 \pm 0.049$ \\
\hline Reaction time $(\mathrm{min})$ & $106.3 \pm 0.013$ \\
\hline 15 & $105.7 \pm 0.002$ \\
\hline 25 & \\
\hline
\end{tabular}

avalues are mean of three determination.

Table 2: Influence of small variation in the assay condition on the analytical performance of the proposed spectrophotometric method for determination of D-penicillamine using NQS reagent.

\begin{tabular}{|c|c|c|c|}
\hline $\begin{array}{l}\text { Taken } \boldsymbol{\mu g} \text { (drug) } \\
\text { D-penicillamine }\end{array}$ & Added $\boldsymbol{\mu g}$ (standard) & Found $\boldsymbol{\mu g}$ & Recovery $(\% \mathbf{\pm}$ SD)a \\
\hline 10 & 2 & 12.46 & $103.83 \pm 0.01$ \\
\hline 10 & 8 & 19.48 & $108.2 \pm 0.006$ \\
\hline 10 & 18 & 27.78 & $99.21 \pm 0.005$ \\
\hline
\end{tabular}

aValues are mean of three determination

Table 3: Determination of D-penicillamine in pharmaceutical preparation, applying standard addition method.

\begin{tabular}{|c|c|}
\hline Dosage form & Recovery $(\% \pm$ SD) \\
\hline D-penicillamine capsule & $104.6 \pm 0.01$ \\
\hline
\end{tabular}

avalues are mean of five determination.

Table 4: Analysis of D-penicillamine containing dosage form by the proposed method.

Recovery of D-penicillamine: To check the validity of the proposed method, the standard addition method was applied by adding D-penicillamine to the previously analyzed D-penicillamine capsule solution. The recovery of each was calculated by comparing the concentration obtained from the spiked mixtures with those of the pure drug. The results of analysis of pharmaceutical dosage form and the recovery study (Table 3 ) suggest that there is no interference from any excipients, which are present in capsules (Table 4).

\section{Reaction mechanism}

It has been reported that NQS could react with amino group of primary amine derivative. Similarly, amino group of D-penicillamine, taking on nucleophilicity due lone electron pair of nitrogen atom, trend to attack on the electron-deficient center in NQS, namely no.4 carbon atom $(3,4-\mathrm{C}=\mathrm{C}$ carbon bond conjugate with $2-\mathrm{C}=\mathrm{O}$, as a result $4-\mathrm{C}$ of NQS becomes electron lacking center). At the same time, it has been proved that the composition of product I is 1:1 of D-penicillamine and NQS (Figure 6). So it is concluded that amino group of D-penicillamine react with 4-sodium sulphonate of NQS molecule respectively, to form 
Citation: Elbashir AA, Awad SF (2013) A New Spectrophotometric Method for Determination of Penicillamine in Pharmaceutical Formulation Using 1 , 2-naphthoquine-4-sulfonate (NQS). J Pharmacovigilance 1: 105. doi:10.4172/2329-6887.1000105

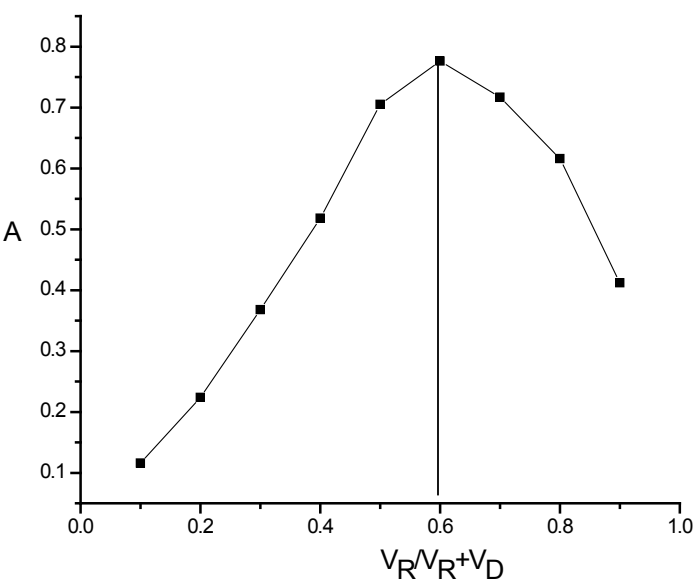

Figure 6: Determination of product I formation by continuous variation method. $\mathrm{V}_{\mathrm{R}}$ : NQS $\left(1 \times 10^{-3} \mathrm{M}\right) ; \mathrm{V}_{\mathrm{D}}$ : D-penicillamine $\left(1 \times 10^{-3} \mathrm{M}\right) ; \mathrm{V}_{\mathrm{R}}+\mathrm{V}_{\mathrm{D}}=10 \mathrm{~mL}$; total volume of reaction solution $11 \mathrm{~mL}$.

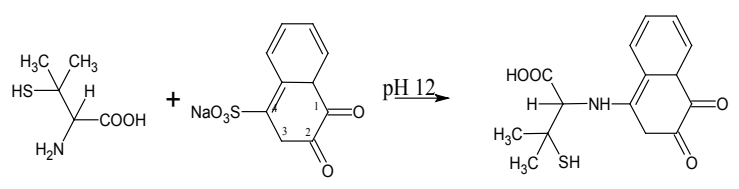

D-penicillamine

NQS

Figure 7: Reaction pathway.

brown N-alkyl-amino-naphthoquinone. The reaction equation is shown in figure 7.

\section{Application of the proposed method to analysis of D-Penicillaminein dosage form}

The pharmaceutical dosage forms (D-penicillamine capsule) were subjected to the analysis of their D-penicillamine content by the proposed method. The label claim percentage was $104.6 \%$, (Table 3 ).

\section{Conclusion}

The procedure presented here does not need necessitate any expensive apparatus and is simple, sensitive and rapid to be carried out. These merits make it applicable for common laboratories. Moreover, this method can be used successfully for the determination of D-Dpenicillamine in pharmaceutical preparations with satisfactory results. Finally, it should be noted that, our method may be applied to the determination of other primary amine derivatives as well.

\section{References}

1. Martindale (1982) The Extra Pharmacopoeia. (28thedn), Pharmaceutical Press, London.

2. Bonta IL, Parnhman MJ, Vincent E, Bragt PC (1980) Anti-rheumatic drugs: present deadlock and new vistas. Prog Med Chem 17: 175-283.

3. Issopoulos PB, Salta SE (1997) High-sensitive spectrophotometric determination of micromolar concentrations of d-penicillamine by means of a coupled redox-complexation reaction. Farm 52: 113-115.

4. Issopoulos PB, Economou PT (1992) Sensitive spectrophotometric determination of micro amounts of d-penicillamine using an indirect redox technique. Anal Chim Acta 257: 203-207.

5. Besada A (1988) A New Simple And Sensitive Spectrophotometric Method For
Determination Of Penicillamine By Reaction With Nitrite And Co(II) Ions. Anal Lett 21: 435-446.

6. Besada A, Tadros NB (1987) A simple colorimetric method for the assay of penicillin $\mathrm{G}$ salt and penicillamine by oxidation with iodate. Mikrochim Acta 2: 225-228.

7. Besada A, Tadros NB, Gawargious YA (1987) Spectrophotometric determination of pure and capsule-formulated Penicillamine. Anal Lett 20: 809-820.

8. Buyuktimkin N, Buyuktimkin S (1985) Spectrophotometric assay of D-penicillamine and its tablets. Pharmazie 40: 581-582.

9. Raggi MA, Vacrini V, Di-Pietra AM (1983) Colorimetric determination of penicillamine in pharmaceutical preparations. Pharm Acta Helv 58: 94-96.

10. Raggi MA, Vacrini V, Di-Pietra AM (1982) Colorimetric determination of acetylcysteine, penicillamine, and mercaptopropionylglycine in pharmaceutical dosage forms. J Pharm Sci 71: 1384-1386.

11. Al-Majed AA(2000) Specific spectrofluorometric quantification of d-penicillamine in bulk and dosage forms after derivatization with 4-fluoro-7-nitrobenzo-2-oxa1,3-diazole. Anal Chim Acta 408: 169-175.

12. Russell J, Mckeown JA, Hensman C, Smith WE, Reglinski J (1997) HPLC determination of biologically active thiols using pre-column derivatisation with 5,5'-dithio-(bis-2-nitrobenzoic acid). J Pharm Biomed Anal 15: 1757-1763.

13. Nhang Z, Baeyens WRG, Zhang X, Zhao Y, Van-Der-Weken G (1997) Chemiluminescence detection coupled to liquid chromatography for the determination of penicillamine in human urine. Anal Chim Acta 347: 325-332.

14. Nakashima K, Ishimaru T, Kuroda N, Akiyama S (1995) High-performance liquid chromatographic separation of penicillamine enantiomers labelled with $\mathrm{N}$-[4-(6-Dimethylamino-2-benzofuranyl)phenyl]maleimide on a chiral stationary phase. Biomed Chromatogr 9: 90-93.

15. Nakashima K, Muraoka M, Nakatsuji S, Akiyama S (1988) Determination of D-penicillamine in serum by high-performance liquid chromatography using $\mathrm{N}$-[4-(6-dimethylamino-2-benzofuranyl) phenyl] maleimide. Japanese Journal of Clinical Chemistry 17: 51-54

16. Busker E, Guenther K, Martens J (1985) Application of chromatographic chiral stationary phases to pharmaceutical analysis. Enantiomeric purity of D-penicillamine. J Chromatogr 350: 179-185.

17. Biffar S, Greely V, Tibbetts D (1985) Determination of penicillamine in encapsulated formulations by high-performance liquid chromatography. J Chromatogr 318: 404-407.

18. Shaw IC, McLean AEM, Boult CH (1983) Analysis of D-penicillamine by high-performance liquid chromatography with glassy carbon electrochemical detection. J Chromatogr 275: 206-210.

19. Miners JO, Fearnley I, Smith KJ, Birkett DJ, Brooks PM, et al. (1983) Analysis of $\mathrm{d}$-penicillamine in plasma by fluorescence derivatisation with $\mathrm{N}$-[p-(2benzoxazolyl)-phenyl] maleimide and high-performance liquid chromatography. J Chromatogr 275: 89-96.

20. Perez-Ruiz T, Martinez-Lozano C, Tomas V, Sidrach-de-Cardona C (1996) Flow-injection fluorimetric determination of penicillamine and tiopronin in pharmaceutical preparations. J Pharm Biomed Anal 15: 33-38.

21. Garcia MS, Sanchez-Pedreno C, Albero MI, Rodenas V (1993) Determination of penicillamine or tiopronin in pharmaceutical preparations by flow injection analysis. J Pharm Biomed Anal 11: 633-638.

22. Vinas P, Sanchez-Prieto JA, Hernandez-Cordoba M (1990) Flow injection analysis and batch procedures for the routine determination of $\mathrm{N}$-penicillamine. Microchem J 41: 2-9.

23. Tewari BB (1988) Electrophoretic studies on mixed complexes: Metalmethionine- penicillamine system. J Chromatogr 793: 220-222.

24. Tewari BB (1996) Paper electrophoresis in the study of mixed ligand complexes in solution. The system $\mathrm{Fe}(\mathrm{III})-$ and $\mathrm{Cr}$ (III)-methyl cysteine penicillamine. Biomed Chromatogr 10: 221-224.

25. Chen C, Pollack GM (1996) Development of a capillary zone electrophoresis assay to examine the disposition of [D-pen2,5]enkephalin in rats. J Chromatogr B Biomed Appl 681: 363-373.

26. Jovanovic T, Koricanacz Z, Stankovic B (1991) Determination of D(-) penicillamine by potentiometric titration. Pharmazie 46: 293-294. 
Citation: Elbashir AA, Awad SF (2013) A New Spectrophotometric Method for Determination of Penicillamine in Pharmaceutical Formulation Using 1 , 2-naphthoquine-4-sulfonate (NQS). J Pharmacovigilance 1: 105. doi:10.4172/2329-6887.1000105

Page 5 of 5

27. Forsman $U$ (1983) The stripping voltammetmc pattern of cysteine and penicillamine at the mercury electrode in the presence of $\mathrm{Cu}(\mathrm{II})$. J Electroana Chem Interfacial Electrochem 152: 241-254.

28. Forsman U, Karlsson A (1981) Polarographic determination of penicilloic acid in penicillin preparations with a flow-injection system. Anal Chim Acta 128: 135142.

29. Fogg AG, Fayad NM (1980) Differential pulse polarographic study of the degradation of ampicillin. Anal Chim Acta 113: 91-96.

30. Nelson J (1981) Nuclear magnetic resonance spectroscopic method for determination of penicillamine in capsules. J Assoc Off Anal Chem 64: 11741178.

31. Hasani M, Yaghoubi L, Abdollahi H (2007) A kinetic spectrophotometric method for simultaneous determination of glycine and lysine by artificial neural networks. Anal Biochem 356: 74-81.

32. LiQM, Yang ZJ (2007) Spectrophotometric determination of aminomethylbenzoic acid using sodium 1,2-naphthoquinone-4-sulfonate as the chemical derivative chromogenic reagent. Spectrochim Acta A 60: 656-661.

33. Darwish IA (2005) Kinetic spectrophotometric methods for determination of trimetazidine dihydrochloride. Anal Chim Acta 551: 222-231.

34. Xu L, Wang H, Xiao Y (2004) Spectrophotometric determination of ampicillin sodium in pharmaceutical products using sodium 1,2-naphthoquinone4-sulfonic as the chromogentic reagent. Spectrochim Acta A Mol Biomol Spectrosc 60: 3007-3012.

35. Ebraheem SAM, Elbashir AA, Abou-Enein HY (2011) Spectrophotometric methods for the determination of gemifloxacin in pharmaceutical formulations. Acta Pharma Sinica 4: 248-253.

36. Ahmed SMA, Elbashir AA, Aboul-Enein HY (2011) New spectrophotometric method for determination of cephalosporins in pharmaceutical formulations. Arabian Journal of Chemistry.

37. Elbashir AA, Ahmed SMA, Aboul-Enein HY (2012) New spectrofluorimetric method for determination of cephalosporins in pharmaceutical formulations. $J$ Fluoresc 22: 857-864.

38. Elbashir AA Elwagee AHE (2012) Spectrophotometric determination of pyrimethamine (PYM) in pharmaceutical formulation using 1,2-naphthoquinone4-sulfonate (NQS). Journal of the Association of Arab Universities for Basic and Applied Sciences 11: 32-36.

39. Elbashir AA, Abir AA, Shazalia MAA, Aboul-Enein HY (2012) 1,2-naphthoquinone-4-sulphonic acid sodium salt (NQS) as an analytica reagent for the determination of pharmaceutical amine by spectrophotometry. Spectroscopy Review 47: 219-232.

40. Job P (1963) Advanced physicochemical Experiments. (2ndedn), Oliner and Boyd, Edinburgh, 196, P-54. 